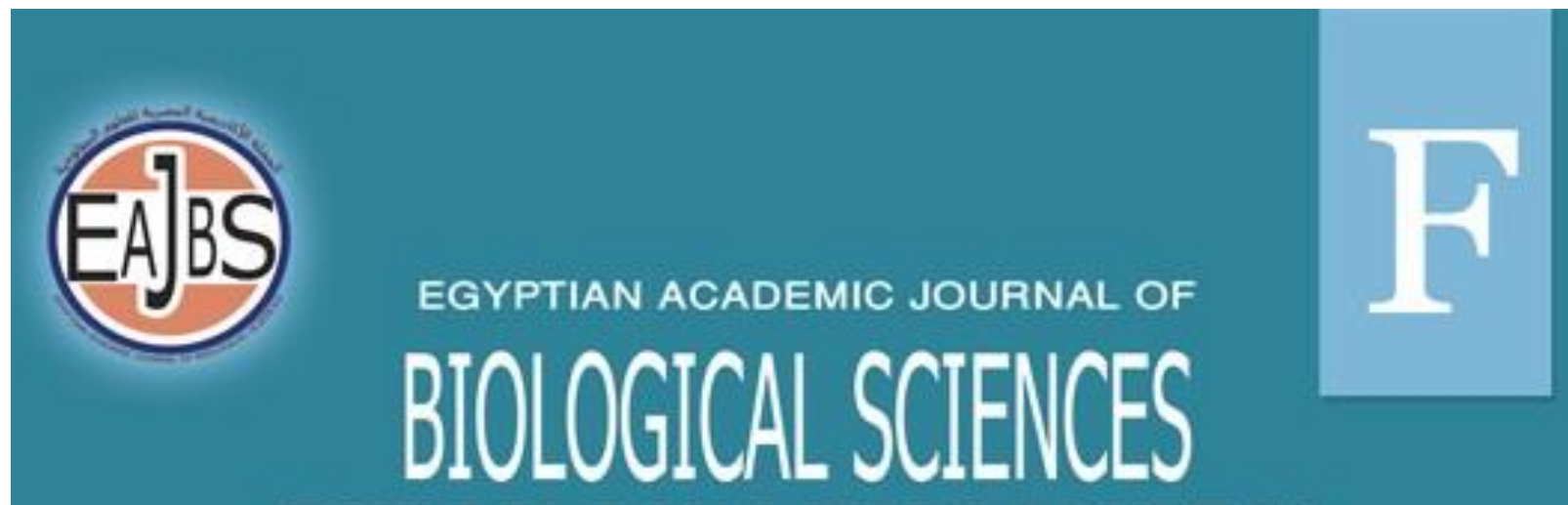

TOXICOLOGY \& PEST CONTROL

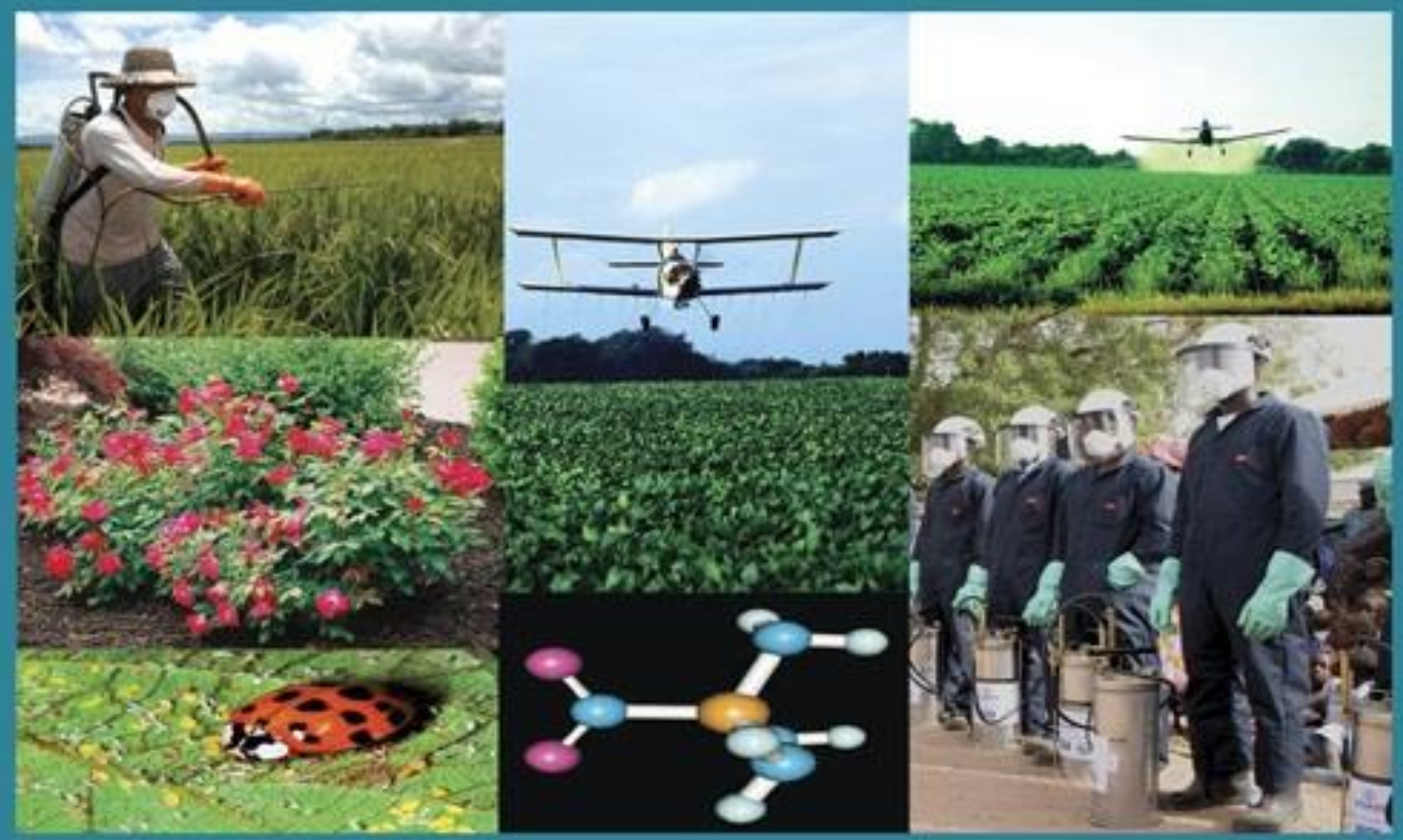

ISSN

2090-0791

WWW.EAJBS.EG.NET

Vol. 13 No. 1 (2021)

$\underline{\text { www.eajbs.eg.net }}$

Citation: Egypt. Acad. J. Biolog. Sci. (F.Toxicology\& Pest control) Vol.13(1)pp279-291(2021)

DOI: 10.21608/EAJBSF.2021.180488 
Egypt. Acad. J. Biolog. Sci., 13(1):279- 291(2021)

Egyptian Academic Journal of Biological Sciences

F. Toxicology \& Pest Control

ISSN: 2090 - 0791

http://eajbsf.journals.ekb.eg/

\title{
Susceptibility of the Egyptian Cotton Leafworm, Spodoptera littoralis (Boisd.) (Lepidoptera: Noctuidae) to Entomocidal Crystal Proteins Cry1Ac and Cry 2Ab Baseline Responses
}

\author{
Ahmed M. A. Salman ${ }^{1}$, Hassan F. Dahi ${ }^{2 *}$ and Asmaa M. A. Bedawi ${ }^{2}$ \\ 1- Plant Protection Dept., Fac. of Agric., Sohag Univ. \\ 2 -Plant Protection Research Institute, ARC, Dokki, Giza, Egypt \\ E-mail*: hassandahi@yahoo.com
}

\begin{abstract}
ARTICLE INFO
Article History

Received: 22/3/2021

Accepted: 10/5/2021

Keywords:

Baseline, Cotton

leafworm,

Spodoptera

littoralis, Cry

1Ac , Cry 2Ab,

Entomocidal

proteins toxins,

Bacillus

thuringiensis

(Bt), Bt cotton,

\section{ABSTRACT}

The present study maybe is the first attempt in Egypt to evaluate the effect of Entomocidal proteins (Cry toxins) from Bacillus thuringiensis (Bt) Cry $1 \mathrm{Ac}$ and Cry 2Ab against the Egyptian cotton leafworm Spodoptera littoralis. The cotton leafworm one of the important Lepidopteran species is the most important pests in cotton fields. It can be controlled using Genetically Modified (GM) crops expressing insecticidal $B t$ proteins like $B t$ cotton and $B t$ corn. The long-term success of this technology demands pest resistance management. Important information for the successful management of resistance is the baseline susceptibility of the different target pests to the different $B t$ proteins. The data on baseline susceptibility should enable risk assessors and managers to assess whether GM cotton produces a $B t$ protein in a high-dose to specific target organisms and resistance has evolved during the commercial cultivation of this GM cotton event. During this study, the toxicity of Cry $1 \mathrm{Ac}$ and Cry $2 \mathrm{Ab}$ from the bacterium Bacillus thuringiensis to larvae of S. littoralis was assessed using first instar larvae with diet incorporation bioassays. Larvae reared (4 generations) from 2 populations of S. littoralis collected from major cotton-growing regions of Sohag and Assuit Governorates were tested. The $\mathrm{LC}_{50}$ for the Assuit strain was 140.11 and $88.54 \mu \mathrm{g} / \mathrm{ml}$ for Cry $1 \mathrm{Ac}$ and Cry $2 \mathrm{Ab}$, respectively. While, the $\mathrm{LC}_{50}$ for the Sohag strain was 410.75 and $37.62 \mu \mathrm{g} / \mathrm{ml}$ for Cry $1 \mathrm{Ac}$ and Cry $2 \mathrm{Ab}$, respectively. On the other hand, the laboratory strain was more sensitive for the same Cry's (Cry $1 \mathrm{Ac}$ and Cry $2 \mathrm{Ab}$ ) the $\mathrm{LC}_{50}$ was 13.40 and $0.23 \mu \mathrm{g} / \mathrm{ml}$, respectively. The lethal concentration $\left(\mathrm{LC}_{50}\right)$ against $S$. littoralis for $2^{\text {nd }}$ and $4^{\text {th }}$ instars larvae when using the $B$. thuringiensis as spores (commercial product) was 1.16 and 2.49 for $2^{\text {nd }}$ and $4^{\text {th }}$ instars, respectively. This study is very important as a preliminary step and baseline ahead of the commercial cultivation and production of Genetically Modified cotton (Bt cotton).
\end{abstract}

\section{INTRODUCTION}

The Egyptian cotton, Gossypium barbadense L., is considered a major economic crop in Egypt; it represents the first cash crop for national income. Thus, the governmental 
policy in Egypt is offering all facilities to encourage farmers to increase the production of cotton in order to meet the increasing requirements for local production and allow surplus for exportation. Several million pounds are paid every year for controlling the cotton pests, the control of $S$. littoralis based mainly on foliage treatments with chemical synthetic insecticides. The widespread and intensive use of different synthetic insecticides for controlling this pest caused increasing environmental problems including insect resistance, excessive persistence of residues, human health hazards and harmful effects on non-target organisms (Dahi, 2012). Bacillus thuringiensis (Bt) is a Gram-positive, soil-dwelling bacterium. Many $B t$ strains produce insecticidal crystal proteins (Cry proteins) during sporulation, as well as vegetative insecticidal proteins (Vips) during vegetative stages of growth (Estruch et al., 1996; Schnepf et al., (1998) and Chakroun et al., (2016). Since 1996, some of these insecticidal $B t$ proteins (mainly Cry proteins) have been incorporated into transgenic crops ( $B t$ crops) for control of several major pests of lepidoptera and coleopteran. In 2015, more than 84 million hectares of $B t$ cotton, corn, and soybean were planted globally James, 2015. The toxins of Bacillus thuringiensis $(B t)$ have shown great potential in the control of harmful insects affecting human health and agriculture, used as the main biological agent for the formulation of bioinsecticides due to its specificity to target different insect orders (David, et al. 2019). The basis of Bt insecticidal activity comes from the $\delta$ endotoxins formed during sporulation (Shelton et al., 2002). After ingestion in the midgut of pests, the $B t$ protoxin is activated by the gut proteases into an active toxin, which binds to specific receptors like cadherin and amino peptidase- $\mathrm{N}$ or alkaline phosphates in the per trophic membrane, forming pores in the midgut epithelial cells (Fortier et al. 2007; Abdullah et al., 2009; and Talaei-Hassanloui et al., 2014). At least ten genes encoding different $B t$ toxins have been engineered into different crops plants: Cry1 Aa, Cry1 Ab, Cry1Ac, Cry1Ba, Cry1Ca, Cry1H, Cry2 Aa, Cry3A, Cry6A and Cry9C (Schuler et al. 1998) and most of the commercial transgenic cotton express Cry1Ac (Luttrell et al. 1999; Perlak et al., 2001; Dutton et al., 2002 and Baur and Boethel, 2003). Genetically modified plants expressing insecticidal proteins from the bacterium Bacillus thuringiensis Berliner (Bt) have been developed and used in agricultural systems to protect crops against damage from the targeted insect pests. The commercial use of the $B t$ cotton product Bollgard expressing the insecticidal protein Cry1 Ac ( $\delta$-endotoxin) was approved by the National Biosafety Technical Commission in Brazil in 2005 Albernaz et al., 2012. Cry2Ab is toxic only to lepidopteran insects (Höfte and Whiteley 1989; Widner and Whiteley 1989; Dankocsik et al. 1990). Cry1Ac has provided significant environmental and economic benefits since its introduction in China in 1997 for control of major lepidopteran pests (Huang, et al., 2002; Lu, et al., 2012; Wu and Guo, 2005; Wu, et al., 2008).

\section{MATERIALS AND METHODS}

\section{Insect Rearing:}

Two laboratory strains of $S$. littoralis were obtained from Plant Protection Research Institute, Cotton Leafworm Department, Dokki, Giza. The first strain was fed on castor oil plants Ricinus communis and the rearing technique was according to Dahi, 1997 as follows:

Egg masses of $S$. littoralis were resulting from a maintained insect culture reared in the laboratory for at least four generations on the fresh leaves of castor oil plant as natural food which resemble the natural food in the field (i.e., cotton leaves). For strain establishment, the eggs were maintained at $27 \pm 2^{\circ} \mathrm{C}$ and $65 \pm 5 \%$ R.H until hatching. Newly hatched larvae were transferred to clean 5-pound glass-Jars covered with muslin and secured with rubber bands. They were provided with fresh castor-oil leaves which were renewed daily until the larvae show the signs of pupation. A thin layer of fine saw-dust was spread 
on the bottom of every glass-Jars to help the successful pupation. Pupae were kept individually in a vial until moth emergence. Ten pairs of newly - emerged moths were confined into oviposition cages. Which consists of conventional mating glass bells $(16 \mathrm{~cm}$. high and $8 \mathrm{~cm}$.diam.) opened at each end. Each mating-glass bell was supplied with a small fresh branch of Nerium oleander to serve as an oviposition site and placed on its wide end on a half petri-dish. Tops of the glass bells were covered with muslin and secured with rubber bands. Cages were examined daily to replace $N$. oleander branches with new ones and renew the adult feeding solution (a small piece of absorbent cotton wool previously soaked in $10 \%$ sucrose solution). The cages were maintained at the same conditions of temperature and \% R.H. Deposited egg- masses were kept in petri-dishes, and then, were available to achieve the different experiments for the toxicity of $B t$ spores (Protecto®) against $2^{\text {nd }}$ and $4^{\text {th }}$ instar larvae of $S$. littoralis laboratory strain. The second strain: the larvae were fed on an artificial diet according to Abdel-Hafez et al., (1982). The rearing technique was according to Dahi, 2005. Newly hatched larvae were fed individually in glass vials $(20 \times 7.5 \mathrm{~cm})$ filled to onethird with the artificial diet, covered with absorbent cotton and held in the same conditions as mentioned above. The larvae pupate usually on the diet's top or between its parts. At the beginning of pupation, the vials were examined daily for transferring the formed pupae individually to clean vials and incubated until moth emergence. Ten pairs of newly emerged cotton leafworm moths were confined in glass oviposition, which consists of a conventional mating glass bell $(16 \mathrm{~cm}$. high and $8 \mathrm{~cm}$. diam). opened at each end. Each mating - glass bell was supplied with a small fresh branch of Nerima oleander to serve as an oviposition site and placed on its wide end on a half petri-dish. Tops of the glass bells were covered with muslin and secured with rubber bands. Cages were examined daily to replace $N$. oleander branches with new ones and renew the adult feeding solution (a small piece of absorbent cotton wool previously soaked in $10 \%$ sucrose solution). The cages were maintained at the same conditions of temperature and \% R.H. deposited egg- masses were kept in petri dishes, and then was available to achieve the different experiments for the toxicity of Cry 1Ac and Cry 2Ab against newly hatched larvae of S. littoralis Assuit and Sohag field strains and laboratory strain.

Field strains of S. littoralis egg masses were collected from Assiut and Sohag Governorates. Then transferred to the laboratory and rearing at least four generations at 27 $\pm 2{ }^{\circ} \mathrm{C}$ and $65 \pm 5 \%$ R.H to become sensitive strains on the semi-artificial diet by the method described as mentioned before.

\section{Tested Compounds:}

1- Bio-insecticide (Protecto) used as a commercial product of Bacillus thuringiensis subsp. Kurstaki contains $32 \times 10^{3} \mathrm{I}$. U/mg). Active ingredient $9.4 \%$ was obtained from Plant Protection Research Institute, Agricultural Research Centre, Egypt.

2- Cry1Ac and Cry2Ab toxins were freeze-dried powders obtained from Monsanto Company, USA.

Cry1Ac and Cry2Ab protoxin is a crystal protein produced by the gram-positive bacterium, Bacillus thuringiensis (Bt) during sporulation. Transgenic Bt cotton expressed Two $B t$ gene, which codes for Cry1Ac and Cry2Ab. Transgenic crops expressing the insecticidal proteins Cry1Ac and Cry2Ab from Bacillus thuringiensis (Bt) are used worldwide to suppress damage by lepidopteran pests, often used in combination between Cry1 Ac and Cry2Ab toxin to delay resistance evolution in $B t$ cotton.

\section{Bioassaying Test:}

To evaluate the $\mathrm{LC}_{50}$ of $B$. thuringiensis Protecto against $2^{\text {nd }}$ and $4^{\text {th }}$ instars larvae of the cotton leafworm, $S$. littoralis by leaf dipping technique. Serial concentrations of $B$. thuringiensis were prepared based on ppm water from $(20,15,10,5,2.5,1.25,0.625,0.312$, 0.156 and 0.078 ) for each instar. Five replicates (each of 10 larvae/concentrations) were 
used. All the castor leaves were dipped for 30 seconds in each concentration, then left to dry under laboratory conditions. Larvae were allowed to feed on treated castor bean leaves (Ricinus communis L.,) for 48 hours then allowed to feed on untreated leaves. Data were recorded after 2, 3, 5, 7 days and the percentage of mortality was estimated.

Two field strains collected from Assiut and Sohag of S. littoralis in 2020 were evaluated for susceptibility to Cry $1 \mathrm{Ac}$ and Cry2Ab. While concentrations $(1500,1000,500$, $100,4,0.8 \mu \mathrm{g} / \mathrm{ml})$ and $(1250,1000,500,100,20,0.8 \mu \mathrm{g} / \mathrm{ml})$ were used for Cry1Ac and Cry2Ab, respectively, for Assiut Strain. Concentrations (1500, 750, 500, 100, 20, $4 \mu \mathrm{g} / \mathrm{ml}$ ) and $(1000,500,100,20,4,0.8 \mu \mathrm{g} / \mathrm{ml})$ were used for Cry1Ac and Cry2Ab, for Sohag Strain, respectively. Additionally, the susceptibility of a laboratory strain of S. littoralis was evaluated at the same time was being tested. Serial concentrations of Cry toxins of Cry1Ac and $\mathrm{Cry} 2 \mathrm{Ab}$ were prepared by diluting with an artificial diet. Cry1 Ac were $(750,500,100$, $20,4,0.8,0.16,0.32 \mu \mathrm{g} / \mathrm{ml})$ and concentrations $(500,100,20,4,0.8,0.16,0.32,0.0064$, $0.00128 \mu \mathrm{g} / \mathrm{ml}$ ) were used for Cry2Ab. Three replicates were used for each of the 20 larvae/concentrations. Control larvae were feed on an artificial diet without toxins. After mixing the toxin with diet (diet-incorporation), neonate offspring were transferred individually with brushes into $1 \mathrm{oz}$ plastic cups. These cups had tight-fitting lids and contained about $5 \mathrm{gm}$ of the diet each. One neonate larva was placed into each cup and the tops were affixed.

A 7-day diet-incorporation bioassay (Wei et al., 2017) was used. After 7-day neonates that developed to $\geq$ the $4^{\text {th }}$ instar stage (Watson and Johnson 1974) were scored as alive and the percentage of mortality was estimated and corrected using Abbott's correction (Abbott 1925). Estimates of $\mathrm{LC}_{50}$, and corresponding 99\% confidence limits, were calculated using probit analysis Finney (1971).

\section{Biological Aspect:}

The larval instars which treated with $\mathrm{LC}_{50}$ of the B. thuringiensis, Cry1Ac and $\mathrm{Cry} 2 \mathrm{Ab}$ were observed for the following biological aspect: larval duration, pupation rate, larval mortality percentage, the pupal duration, pupal weight, percentage, sex ratio, malformation, intermediate shape, emergence, and pupal mortality, female and male longevity, adult longevity, pre-oviposition, oviposition, post-oviposition period, fertility $\%$ and Incubation period.

\section{RESULTS AND DISCUSSION}

\section{Toxicity of $B$. thuringiensis as spores against $2^{\text {nd }}$ and $4^{\text {th }}$ instars larvae of $S$. littoralis under laboratory conditions.}

The toxic action as the initial toxic effect of the investigated compound to the $2^{\text {nd }}$ and $4^{\text {th }}$ instars larvae of $S$. littoralis was evaluated under laboratory conditions. The main criteria of the toxicity regression line, $\mathrm{LC}_{50}$ and slope value were used as a parameter to determine the level of toxicity for $B$. thuringiensis when using it as spores (commercial product).

Data summarized in Table (1), showed that the toxic effect of $B$. thuringiensis spores represented as $\mathrm{LC}_{50}$ 's against $S$. littoralis for $2^{\text {nd }}$ and $4^{\text {th }}$ instars. $\mathrm{LC}_{50}$ was 1.1631 and 2.498 for $2^{\text {nd }}$ and $4^{\text {th }}$ instars, respectively, (Figs. $1 \&$ 2). Harapaz and Wysoki (1984) found that $1 \%$ concentration of $B$. thuringiensis wettable powder (containing $16.000 \mathrm{lU} / \mathrm{mg}$ ) applied at a rate of $48.000 \mathrm{IU} / \mathrm{cm} 2$, killed $95 \%$ of 4 th instar larvae of carob moth, Ectomyelcis ceratoniae (Zeller) (Lepidoptera: Pyralidae), after $66 \mathrm{~h}$. Meanwhile, 100\% mortality was recorded after $85 \mathrm{~h}$ of exposure in a laboratory test. The mortality caused by $0.5 \%$ concentration $(24.000$ $1 \mathrm{U} / \mathrm{cm} 2$ ) was significantly lower and presumably inadequate for practical application against this pest. Yamamoto et al., (1990) evaluated the effect of $B$. thuringiensis, cyfluthrin and fenvalerate on the larvae of Alabama argillacea. Fenvalerate gave $60 \%$ control and $B$. 
thuringiensis was the least effective controlling less than $50 \%$ up to 6 days after application. A significant reduction in the pupal population 6 days after application of $B$. thuringiensis indicated some secondary effect on the larvae before pupation. Also, Mohamed et al., 2011, studied the toxic effects of entomopathogenic bacterium, Bacillus thuringiensis subsp. Kurstaki on the larval instars of the Sesamia cretica (Lederer) and the same trend for toxic effect was observed.

Table 1: Toxicity of $B$. thuringiensis as spores (commercial product) against the $2^{\text {nd }}$ and $4^{\text {th }}$ instars larvae of $S$. littoralis

\begin{tabular}{|c|c|c|c|}
\hline Biocide & Larval instar & LC $_{\mathbf{5 0}}(\mathbf{p p m})$ & Slope \\
\hline \multirow{2}{*}{$\begin{array}{c}\text { B. thuringiensis } \\
\text { (Protecto } 囚)\end{array}$} & $2^{\text {nd }}$ & 1.1631 & 0.0835 \\
\cline { 2 - 4 } & $4^{\text {th }}$ & 2.498 & 0.1256 \\
\hline
\end{tabular}

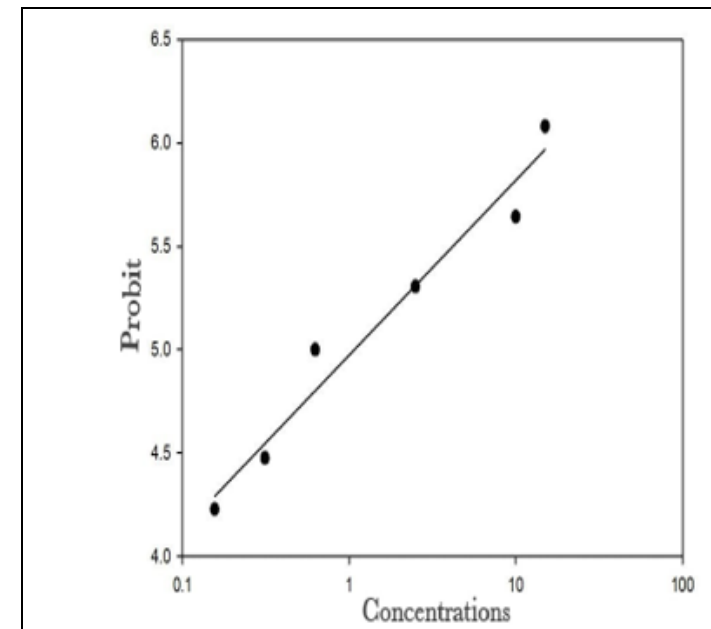

Fig.1: Toxicity line of $B t$ spores against $S$. littoralis $2^{\text {nd }}$ instar larvae

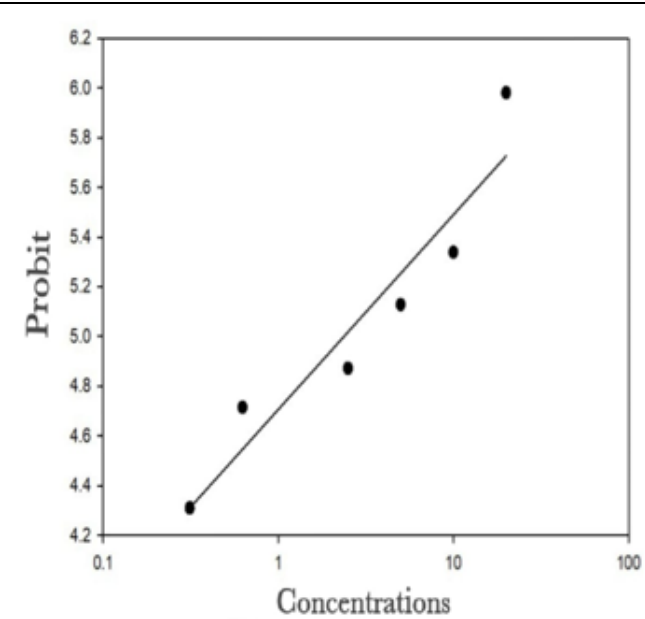

Fig.2; Toxicity line of $B t$ spores against $S$. littoralis $4^{\text {th }}$ instar larvae

\section{Toxicity of Cry1Ac and Cry2Ab against Newly Hatched Larvae of S. littoralis Field and Laboratory Strains.}

Data presented in Table (2), show that the efficacies of tested $B t$ toxins represented

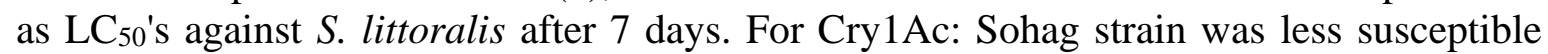
than Assiut strain. The $\mathrm{LC}_{50}$ of Sohag strain was $410.75 \mu \mathrm{g} / \mathrm{ml}$, while, the $\mathrm{LC}_{50}$ of Assiut strain was $140.11 \mu \mathrm{g} / \mathrm{ml}$. (Figs. $5 \& 7$ ).For Cry2Ab: Sohag strain was more susceptible than Assiut strain. The LC $\mathrm{L}_{50}$ of Assiut strain was $37.620 \mu \mathrm{g} / \mathrm{ml}$ while the $\mathrm{LC}_{50}$ of Sohag strain was $88.539 \mu \mathrm{g} / \mathrm{ml}$. (Figs. $6 \&$ 8).For laboratory strain: Cry2Ab was higher effectiveness than Cry1Ac. (Figs. 3 \&4). Yiyun et al., (2017) studied the same point on Helicoverpa armigera in China, the study reported the control of this pest has been dependent on transgenic cotton producing a single Bacillus thuringiensis (Bt) protein Cry1Ac since 1997. A small, but significant, increase in $H$. armigera resistance to Cry1Ac was detected in field populations from Northern China. Since Vip3Aa has a different structure and mode of action than Cry proteins, Bt cotton pyramids containing Vip3Aa are considered as ideal successors of Cry1 Ac cotton in China. In this study, the baseline susceptibility of $H$. armigera to Vip3Aa was evaluated in geographic field populations collected in 2014 from major cottonproducing areas of China. The $\mathrm{LC}_{50}$ values of 12 field populations ranged from 0.053 to $1.311 \mu \mathrm{g} / \mathrm{cm}^{2}$, representing a 25 -fold range of natural variation among populations. It is also demonstrated that four laboratory strains of $H$. armigera with high levels of resistance to Cry1Ac or Cry2Ab have no cross-resistance to Vip3Aa protein. The baseline susceptibility 
data established here will serve as a comparative reference for the detection of field-evolved resistance to Vip3Aa in $H$. armigera after future deployment of $B t$ cotton pyramids in China. Unnithan et.al., 2004, studied the Susceptibility of pink bollworm (PBW), Pectinophora gossypiella, to the $B t$ toxin Cry2Ab was evaluated on collections made in the Southwestern U.S. in 2001 and 2002 and contrasted with laboratory strains. PBW were collected from cotton fields, cultured in the laboratory, and tested using diet-incorporation bioassays. A total of 6 collections in 2001 and 14 collections in 2002 were successfully reared and bioassayed. Significant differences between strains in susceptibility to Cry2Ab were found each year, though the range of susceptibility was substantially greater in 2001 than in 2002. $\mathrm{LC}_{50}$ estimates of strains ranged from 0.220 to $4.56 \mu \mathrm{g}$ Cry $2 \mathrm{Ab} / \mathrm{ml}$ and 0.0840 to $0.723 \mu \mathrm{g}$ Cry2Ab/ml in 2001 and 2002, respectively. Only one field strain, a collection from Tornillo, Texas, was substantially less susceptible to Cry2Ab than was the laboratory strain, AZP-R, which was highly resistant to Cry1 Ac. Based on these baseline responses, concentrations of 1.0 and $10 \mu \mathrm{g}$ Cry $2 \mathrm{Ab} / \mathrm{ml}$ diet have been identified for routine monitoring of pink bollworm. Selection of 2001 and 2002 strains with Cry2Ab is underway in the laboratory but has not yielded intense resistance to Cry2 Ab. Thus, at this time we have no indication of significant resistance of Southwestern pink bollworm to the second $B t$ toxin being deployed in transgenic insecticidal cotton.

Table 2: Toxicity of Cry1Ac and Cry2Ab against newly hatched larvae of S. littoralis field and laboratory strains.

\begin{tabular}{|c|c|c|c|}
\hline Strains & Cry Toxin & $\mathbf{L C}_{\mathbf{5 0}}(\boldsymbol{\mu} \mathbf{g} / \mathbf{m l})$ & Slope \\
\hline \multirow{2}{*}{ Assiut strain } & Cry1Ac & 140.11 & 0.1592 \\
\cline { 2 - 4 } & Cry2Ab & 88.54 & 0.1757 \\
\hline \multirow{2}{*}{ Sohag strain } & Cry1Ac & 410.75 & 0.2910 \\
\cline { 2 - 4 } & Cry2Ab & 37.62 & 0.1148 \\
\hline \multirow{2}{*}{ Laboratory strain } & Cry1Ac & 13.40 & 0.1071 \\
\cline { 2 - 4 } & Cry2Ab & 0.23 & 0.0255 \\
\hline
\end{tabular}

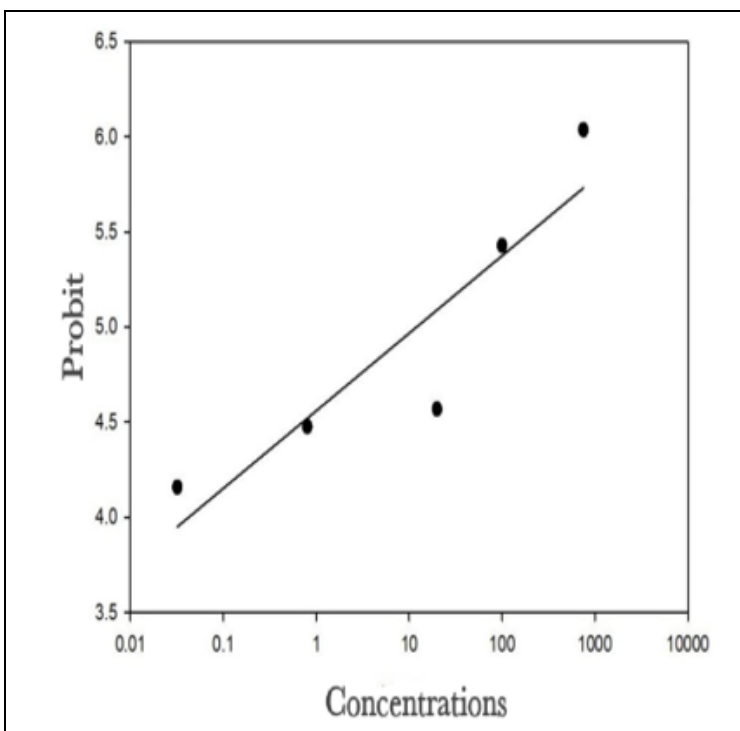

Fig. 3: Toxicity line of Cry1Ac against $S$. littoralis laboratory strain

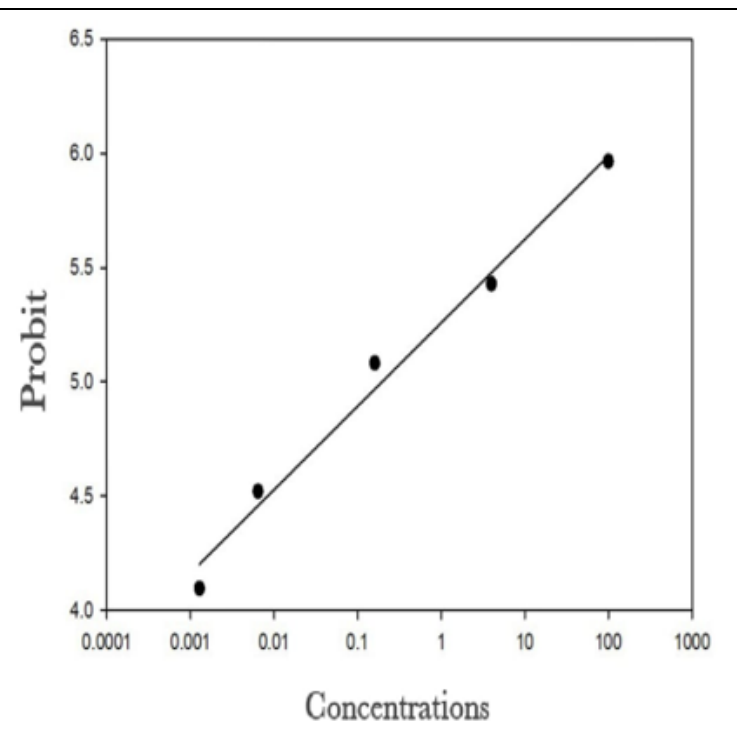

Fig. 4: Toxicity line of Cry2Ab against $S$. littoralis laboratory strain 


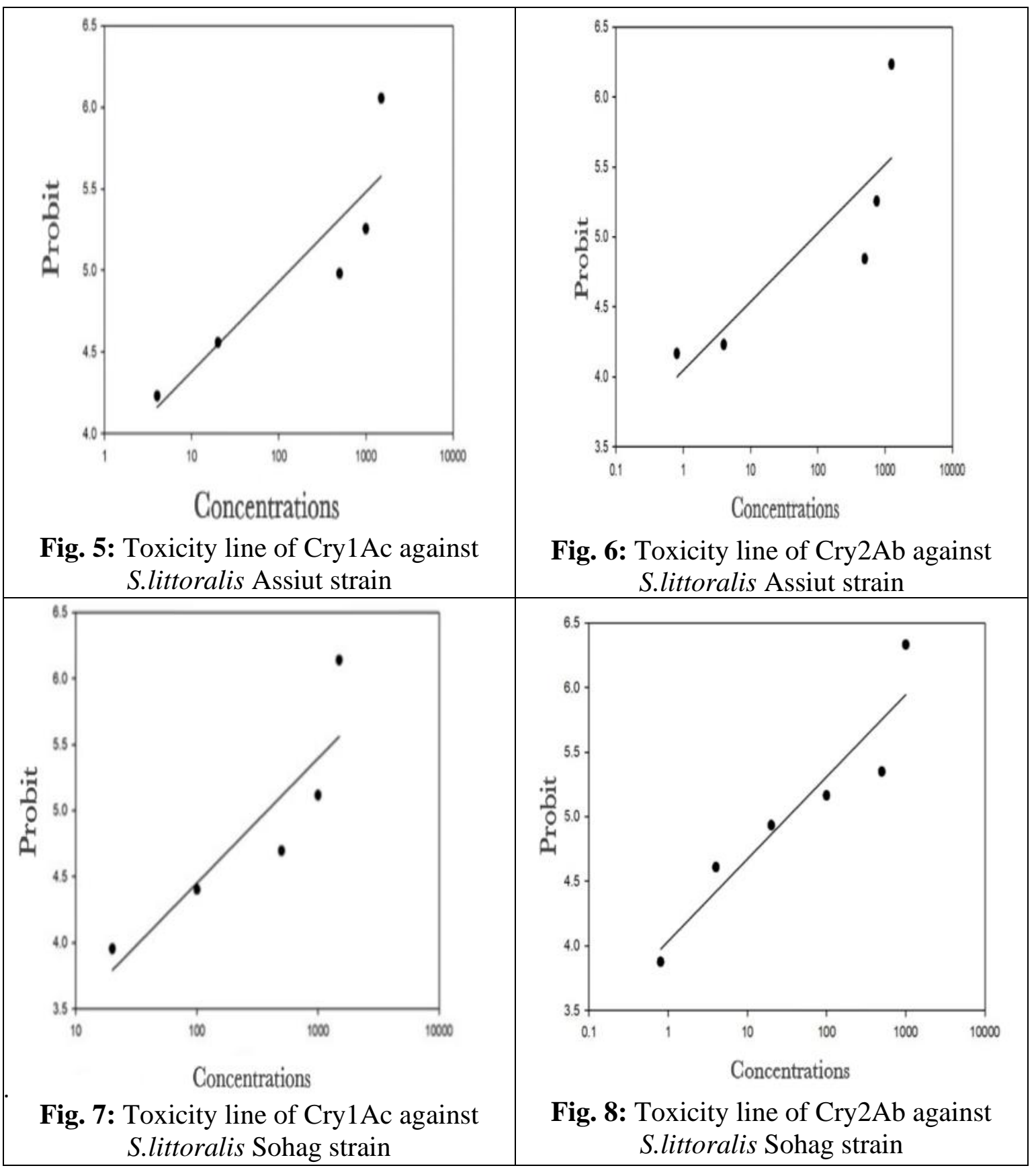

\section{Effects of B. thuringiensis (Bt) As Spores on Biological Aspects for S. littoralis:}

Data in Table (3) show that the biological aspects for $2^{\text {nd }}$ and $4^{\text {th }}$ instars larvae of $S$. littoralis after treated with Bacillus thuringiensis $(B t)$ spores. For the $2^{\text {nd }}$ instar larvae: the larval duration was 14.85 days compared with control (15.56 days). The pupation $\%$ and larval mortality \% were 48.0 and 52.0 compare with control 98.0 and $2.0 \%$, respectively. The pupal duration, pupal weight and sex ratio were 10.3, 0.2262 and 50:50 compare with control 8.78 days, $0.2276 \mathrm{gm}$ and 46.9: $53.1 \mathrm{q}: \hat{\jmath}$, respectively. While, the percentages of malformation, intermediate shape, emergence and pupal mortality were 24.0, 4.4, 93.75 and $6.25 \%$ compare with control 2.04, 0.0, 100.0 and $0.0 \%$, respectively. On the other hand, for the adult stage, the female and male longevities were 9.0 and 7.0 compare with the control 9.33 and 8.33 days, respectively. The female pre-oviposition period, oviposition period and post oviposition period were 1.66, 4.66 and 2.66 compared with control 2.0, 4.66 and 2.66 days, respectively. The fecundity (No. egg / $q$ ) and fertility \% for S. littoralis when the 
larvae treated in $2^{\text {nd }}$ instar were 844.66 and 92.0 compared with control $1961.33 \mathrm{egg} / q$ and 100.0, respectively. The adult longevity was 8.0 and 8.33 days for treatment and control, respectively. The incubation period for egg stage at the next generation after treatment $S$. littoralis $2^{\text {nd }}$ instar larvae with $B t$ spores was 3.43 compared with control 3.38 days. For the $4^{\text {th }}$ instar larvae: the larval duration was 9.35 days compared with control (10.57 days). The pupation \% and larval mortality \% were 58.0and 42.0 compare with control 96.0 and $4.0 \%$, respectively. The pupal duration, pupal weight and sex ratio were $8.71,0.2249$ and 53.57:49.0: 46.43 compare with control 8.12 days, $02301 \mathrm{gm}$ and 49.0:51.0 $\mathrm{O}$ : ô, respectively. While, the percentages of malformation, intermediate shape, emergence and pupal mortality were $20.68,3.44,100.0$ and $0.0 \%$ compare with control 0.0, 0.0, 100.0 and $0.0 \%$, respectively. On the other hand, for the adult stage, the female and male longevities was 8.33 and 7.33 compared with control 9.32 and 8.66 days, respectively. The female preoviposition period, oviposition period and post oviposition period were 1.0, 4.00 and 3.33 compared with control 1.9, 4.76 and 2.66 days, respectively. The fecundity (No. egg / $\$$ ) and fertility $\%$ for $S$. littoralis when the larvae treated in $4^{\text {th }}$ instar were 1556.0 and 95.0 compared with control $1709.0 \mathrm{egg} / q$ and 100.0, respectively. The adult longevity was 7.82 and 8.32 days for treatment and control, respectively. The incubation period for egg stage at the next generation after treatment $S$. littoralis $4^{\text {th }}$ instar larvae with $B t$ spores was 3.38 compared with control 3.07 days. Mona et al., (2011) clear that the efficacy of three Bacillus thuringiensis formulations, Agerin, Dipel 2X and Dipel DF were tested against 2nd larval instar of Spodoptera littoralis. The three formulations were tested in the laboratory, field and semi-field experiments. The 48-hour LC50 for Agerin, Dipel 2X and Dipel DF were 0.18, 0.07 and $0.10 \%$ for the three formulations, respectively. The results of the field experiment indicated that the general mean of reduction was 59.0, 55.9 and $58.6 \%$ for the three $B t$ formulations (Agerin, Dipel 2Xand Dipel DF, respectively). In addition, the general mean of mortality rate in the semi-field experiments was 60.3, 60.4 and $61.3 \%$ for Agerin, Dipel $2 \mathrm{X}$ and Dipel DF, respectively. On the other hand, Mohamed et al., (2011), reported that The $\mathrm{LC}_{50}$ value after 48 hours from treatment, of $B$. thuringiensis for $1^{\text {st }}$ instar and $2^{\text {nd }}$ larvae were 0.00526 and $0.7 \mathrm{gm}$, respectively. After treatment of $1^{\text {st }}$ and $2^{\text {nd }}$ instars larvae of $S$. cretica with $\mathrm{LC}_{50}$ concentrates of $B$. thuringiensis, the average larval duration of $S$. cretica were $(36.53 \& 24.69)$ and $(33.78 \& 20.31)$ days for treated and untreated, respectively. In addition, the pupation percentage was $(47 \& 92 \%)$ and $(18 \& 84 \%)$ for treated and untreated, respectively. The larval mortality percentage was (53\& $8 \%$ ) and (82 \& $16 \%)$ for treated and untreated, respectively. The pupal weight for (treated \& untreated), S. cretica were $(0.1887 \& 0.184 \mathrm{gm})$ and $(0.1842 \& 0.1601 \mathrm{gm})$ when it treated as $1^{\text {st }}$ and $2^{\text {nd }}$ instars larvae, respectively. Furthermore, the pupal duration were (12.14 \& 10) and (10.44 \& 9.83 days) for (treated $\&$ untreated), when $S$. cretica was treated as $1^{\text {st }}$ and $2^{\text {nd }}$ instar larvae, respectively. The total adult emergence for $1^{\text {st }}$ instar and $2^{\text {nd }}$ instar larvae were $(94 \& 100 \%)$ and $(100 \& 100 \%)$ for treated and untreated, respectively.

\section{Effects of Cry1Ac and Cry 2Ab Toxins on biological aspects for $S$. littoralis:}

Data in Table (4) show that the biological aspects for newly hatched larvae of $S$. littoralis after feeding on protein toxins Cry1 Ac and Cry 2Ab (diet-incorporation). The $S$. littoralis larval duration was 23.62, 25.42 and 17.73 days for Cry1 Ac, Cry 2Ab and control, respectively. The pupation \% was 41.0, 43.0 and $99.0 \%$ for Cry1Ac, Cry $2 \mathrm{Ab}$ and control, respectively, while the larval mortality were 59.0, 57.0 and $1.0 \%$ for Cry1 Ac, Cry $2 \mathrm{Ab}$ and control, respectively. For pupal stage, the pupal duration (days) and pupal weight (gm) were 10.29 and 0.2256 for Cry1Ac; 9.39 and 0.2256 for Cry $2 \mathrm{Ab}$ and 9.65 days and $0.2276 \mathrm{gm}$ for control, respectively. The pupal mortality was 7.32, 9.50 and $1.0 \%$ for Cry $1 \mathrm{Ac}, \mathrm{Cry} 2 \mathrm{Ab}$ and control, respectively. For the adult stage: the sex ratio ( $\left(+:{ }^{7}\right)$ were 48.48: 51.52, 52.56:47.22 and 41.41:58:59 for Cry1 Ac, Cry 2Ab and control, respectively, respectively. 
While, the percentages of malformation, intermediate shape, emergence were 26.32, 13.16 and $92.68 \%$ for Cry $1 ; 20.51,7.69$ and $90.69 \%$ for Cry $2 \mathrm{Ab}$ and 4.04, 1.01 and $99.0 \%$ for control, respectively. On the other hand, for the adult stage, the female, male and adult longevities were 8.33, 7.0 and 7.67 days for Cry1Ac, 8, 98, 8.67 and8.83 days for Cry 2Ab and $10.43,8.33$ and 9.38 days for control, respectively. The female pre-oviposition period, oviposition period and post oviposition period were 1.33, 5.00 and 2.00 for Cry1 Ac, 1.66, 4.66 and 2.66 days for Cry $2 \mathrm{Ab}$ and $1.77,6.00$ and 2.66 days for control, respectively. The fecundity (No. egg / $q$ ) and fertility $\%$ for S. littoralis when the new hatched larvae feed on diet-incorporation (7- days) with $B t$ two toxins were 1895.7 and 89.0 ( for Cry 1Ac), 1716.7 and 85.0 (for Cry 2Ab) and $2276.0 \mathrm{egg} / \mathrm{q}$ (for control), respectively. The incubation period for the egg stage of $S$. littoralis in the next generation when diet-incorporation (7- days) with $B t$ two toxins was 3.47, 3.65 and 3.30 days for Cry1Ac, Cry 2Ab and control, respectively. On the other hand, in South Africa Britz et al., (2020), studied the susceptibility of Spodoptera littoralis to Bt cotton, expressing Cry1 Ac and Cry2Ab Toxins, and reported that the bioassays conducted with S. littoralis in Egypt (Dahi, 2012) showed that the effects of these Cry proteins on growth, development and metamorphosis of S. littoralis were similar to those observed in this study. This author also reported that the pest was highly susceptible to $B t$ cotton and that there was no larval survival after five days of feeding on Giza 80 cotton that expresses both Cry1 Ac and Cry2Ab toxins.

Table 3: Biological aspect of Spodoptera littoralis $2^{\text {nd }}$ and $4^{\text {th }}$ instars larvae after feeding on Bacillus thuringiensis $(\mathrm{Bt})$ spores.

\begin{tabular}{|l|c|c|c|c|}
\hline \multirow{2}{*}{ Biological aspect } & \multicolumn{2}{c|}{ 2 $^{\text {nd }}$ instar larvae } & \multicolumn{2}{c|}{ 4th instar larvae } \\
\cline { 2 - 5 } & Treatment & Control & Treatment & Control \\
\hline Larval duration (days) & $14.85 \pm 0.11$ & $15.56 \pm 0.15$ & $9.35 \pm 0.21$ & $10.57 \pm 0.15$ \\
\hline Pupation \% & 48.0 & 98.0 & 58.0 & 96.0 \\
\hline Larval mortality \% & 52.0 & 2.0 & 42.0 & 4.0 \\
\hline pupal duration (days) & $10.3 \pm 0.28$ & $8.78 \pm 0.15$ & $8.71 \pm 0.26$ & $8.12 \pm 0.27$ \\
\hline Pupal weight (gm) & $0.2262 \pm 0.007$ & $0.2276 \pm 0.023$ & $0.2249 \pm 0.008$ & $0.2301 \pm 0.023$ \\
\hline Sex Ratio 9: 0 & $50: 50$ & $46.9: 53.1$ & $53.57: 46.43$ & $49.0: 51.0$ \\
\hline Malformation \% & 24.0 & 2.04 & 20.68 & 0.0 \\
\hline Intermediate shape \% & 4.4 & 0.0 & 3.44 & 0.0 \\
\hline Emergence \% & 93.75 & 100.0 & 100.0 & 100.0 \\
\hline Pupal mortality \% & 6.25 & 0.0 & 0.0 & 0.0 \\
\hline Female longevity (days) & $9.0 \pm 0.47$ & $9.33 \pm 0.58 .027$ & $8.33 \pm 0.54$ & $9.32 \pm 0.27$ \\
\hline Male longevity (days) & $7.0 \pm 0.47$ & $8.33 \pm 0.27$ & $7.33 \pm 0.27$ & $8.66 \pm 0.27$ \\
\hline Pre-oviposition period (days) & $1.66 \pm 0.27$ & $2.0 \pm 0.0$ & $1.0 \pm 0.0$ & $1.9 \pm 0.0$ \\
\hline oviposition period & $4.66 \pm 0.27$ & $4.66 \pm 0.27$ & $4.0 \pm 0.0$ & $4.76 \pm 0.27$ \\
\hline Post-oviposition period (days) & $2.66 \pm 0.27$ & $2.66 \pm 0.27$ & $3.33 \pm 0.54$ & $2.66 \pm 0.27$ \\
\hline Fecundity (No. egg / ) & 844.66 & 1961.33 & 1556.00 & 1709.33 \\
\hline Adult longevity (days) & $8.0 \pm 0.47$ & $8.83 \pm 0.136$ & $7.82 \pm 0.62$ & $8.32 \pm 0.136$ \\
\hline Fertility \% & 92.0 & 100.0 & 95.0 & 100.0 \\
\hline Incubation period (days) & $3.43 \pm 0.06$ & $3.38 \pm 0.01$ & $3.38 \pm 0.14$ & $3.07 \pm 0.01$ \\
\hline
\end{tabular}


Table 4: Biological aspect of Spodoptera littoralis new hatched larvae after feeding on Entomocidal toxic protein Cry1 Ac and Cry2Ab

\begin{tabular}{|l|c|c|c|}
\hline \multicolumn{1}{|c|}{ Biological aspect } & Cry1Ac & Cry2Ab & Control \\
\hline Larval duration (days) & $23.62 \pm 0.35$ & $25.42 \pm 0.52$ & $17.73 \pm 0.09$ \\
\hline Pupation \% & 41.0 & 43.0 & 99.0 \\
\hline Larval mortality \% & 59.0 & 57.0 & 1.0 \\
\hline pupal duration (days) & $10.29 \pm 0.015$ & $9.36 \pm 0.028$ & $9.65 \pm 0.087$ \\
\hline Pupal weight (gm) & $0.2256 \pm 0.008$ & $0.2256 \pm 0.003$ & $0.2676 \pm 0.006$ \\
\hline Sex Ratio \%o : 0 & $48.48: 51.52$ & $52.56: 47.22$ & $41.41: 58.59$ \\
\hline Malformation \% & 26.32 & 20.51 & 4.04 \\
\hline Intermediate shape \% & 13.16 & 7.69 & 1.01 \\
\hline Emergence \% & 92.68 & 90.69 & 99.0 \\
\hline Pupal mortality \% & 7.32 & 9.30 & 1.0 \\
\hline Female longevity (days) & $8.33 \pm 0.27$ & $8.98 \pm 0.00$ & $10.43 \pm 0.27$ \\
\hline Male longevity (days) & $7.0 \pm 0.47$ & $8.67 \pm 0.27$ & $8.33 \pm 0.27$ \\
\hline Pre-oviposition period(days) & $1.33 \pm 0.27$ & $1.66 \pm 0.27$ & $1.77 \pm 0.27$ \\
\hline Oviposition period(days) & $5.0 \pm 0.47$ & $4.66 \pm 0.27$ & $6.0 \pm 0.54$ \\
\hline Post-oviposition period & $2.0 \pm 0.0$ & $2.66 \pm 0.27$ & $2.66 \pm 0.27$ \\
\hline Fecundity (No. egg / ( ) & 1895.7 & 1716.7 & 3276.0 \\
\hline Adult longevity (days) & $7.67 \pm 0.14$ & $8.83 \pm 0.14$ & $9.38 \pm 0.27$ \\
\hline Fertility \% & 89.0 & 85.0 & 100.0 \\
\hline Incubation period (days) & $3.47 \pm 0.14$ & $3.65 \pm 0.11$ & $3.3 \pm 0.04$ \\
\hline
\end{tabular}

\section{REFERENCES}

Abbott, W. S. (1925): A method of computing the effectiveness of an insecticide. Journal of Economic Entomology, 18: 265 - 267.

Abdel-Hafez, A.; M. A. El-Banby; A. G. Metwalley and M. R. A. Saleh (1982): Rearing of pink bollworm Pectinophora gossypiella (Saunders) on kidney bean diet. Research. Bulletin. Faculty of Agriculture Zagazig University, 576: 1-10.

Abdullah, M. A. F.; Moussa, S.; Taylor, M. D. and Adang, M. J. (2009): Manduca sexta (Lepidoptera: Sphingidae) cadherin fragments function as synergists for Cry1A and Cry1C Bacillus thuringiensis toxins against noctuid moths Helicoverpa zea, Agrotis ipsilon and Spodoptera exigua. Pest Management Science, 65: (10) 1097-1103.

Albernaz K. C.; Merlin B. L.; Martinelli S.; Head G. P. and Omoto C. (2012): Baseline Susceptibility to Cry1Ac Insecticidal Protein in Heliothis virescens (Lepidoptera: Noctuidae) Populations in Brazil. Journal of Economic Entomology, 106(4):18191824.

Baur, M. E. and Boethel, D. J. (2003): Effect of Bt-cotton expressing Cry1A(c) on the survival and fecundity of two hymenopteran parasitoids (Braconidae, Encyrtidae) in the laboratory. Biological Control, 26: 325-332.

Britz, C.; Johnnie V. D. B. and Hannalene D. P. (2020): Susceptibility of Spodoptera littoralis (Boisduval) (Lepidoptera: Noctuidae) to Bt Cotton, Expressing Cry1 Ac and Cry2Ab Toxins, in South Africa. African Entomology, 28(1):182-186.

Chakroun M., Banyuls N., Bel Y., Escriche B. and Ferre J. (2016): Bacterial vegetative insecticidal proteins (Vip) from entomopathogenic bacteria. Microbiology Molecular Biology. Review, 80:329-350.

Dahi, H. F. (1997): New approach for management the population of cotton leafworm Spodoptera littoralis (Boisd.) and pink bollworm Pectinophora gossypiella (Saund.) in Egypt. M.Sc. Thesis, Fac. Agric., Cairo University, 149 pp. 
Dahi H.F. (2005). Egyptian cotton leafworm Spodoptera littoralis (Boisd.) development on artificial diet in relation to heat unit requirements. Egyptian Journal of Agriculture Research, 83(1). 199-209

Dahi, H. F. (2012): Efficacy of $B t$ transgenic Egyptian cotton varieties expressing Cry1Ac and Cry2Ab genes against Spodoptera littoralis (Boisd.). Journal of American Science, 8 (3): $457-463$.

Dankocsik, C., Donovan, W. P. and Iany, C.S. (1990): Activation of a cryptic crystal protein gene of Bacillus thruingiensis subspecies kurstaki by gene fusion and determination of the crystal protein insecticidal specificity. Molecular Microbiology, 4:20872094.

Dutton, A.; Klein, H.; Romeis, J. and Bigler, F. (2002): Uptake of Bt toxin by herbivores feeding on transgenic maize and consequences for the predator Chrysoperla carnea. Ecological Entomology, 27: 441-447.

Estruch J. J., Warren G. W., Mullins M. A., Nye G. J., Craig J. A. and Koziel M. G. (1996): Vip3A, A novel Bacillus thuringiensis vegetative insecticidal protein with a wide spectrum of activities against lepidopteran insects. National Academy of Sciences, USA. 93:5389-5394.

Fernández-Chapa, D.; Ramírez-Villalobos, J. and Galán-Wong, L. (2019): Toxic Potential of Bacillus thuringiensis: An Overview. In Protecting Rice Grains in the PostGenomic: London, U.K.

Finney, D. J. (1971): Probit Analysis. $3^{\text {rd }}$ Edition, Cambridge University Press, Cambridge.

Fortier, M.; Vachon, V.; Frutos, R., Schwartz, J. L. and Laprade, R. (2007): Effect of insect larval midgut proteases on the activity of Bacillus thuringiensis Cry toxins. Apply Environment Microbiology, 73:6208-6213.

Harapaz, I. and Wysoki M. (1984): Susceptibility of the Carob moth Ectomyelois ceratoniae to Bacillus thuringiensis. Phytoparasitica. 12 (3-4):189-191.

Höfte, H. and Whiteley, H. R. (1989): Insecticidal crystal protein of Bacillus thuringiensis. Microbiology Review, 53:242-255

Huang, J.; Rozelle, S. D.; Pray, C. E. and Wang, Q. (2002): Plant biotechnology in China. Science, 295, 674-677.

James C. (2015):20 ${ }^{\text {th }}$ Anniversary (1996 to 2015) of the Global Commercialization of Biotech Crops and Biotech Crop Highlights. ISAAA; Ithaca, NY, USA

Lu, Y. H.; Wu, K. M.; Jiang, Y. Y.; Guo, Y. Y. and Desneux, N. (2012): Widespread adoption of $B t$ cotton and insecticide decrease promotes biocontrol services. Nature, 487, 362-365.

Luttrell, R. G.; Wan, L. and Knighten, K. (1999): Variation of susceptibility of Noctuidae (Lepidoptera) larvae attacking cotton and soybean to purified endotoxins proteins and commercial formulations of Bacillus thuringiensis. Economic Entomology, 92 (1):21-32.

Mohamed, Z. Y. Ali; M. M. Soliman; E. E. Mohamed; H. F. Dahi and sherehan A. R. Salem (2011): Assessment the toxic effects of entomopathogenic bacterium, Bacillus thuringeinsis subsp. Kurstaki and methomyl insecticide on larval instars of the greater sugarcane borer; Sesamia creatica (lederer). Egyptian Academic Journal of Biological Sciences, F. Toxicology ad Pest Control, Vol. 3(1): 1-9.

Mona F. Abd - El Aziz; Nehad M. Elbarky; and H. F. Dahi (2011): Efficacy of different Bacillus Thuringiensis formulations for the control of the cotton leafworm Spodoptera littoralis (Boisd.) (Lepidoptera: Noctuidae). Journal of American Science, 7 (6), 863- 871.

Perlak, F. J.; oppenhuizen, M.; Gustafson, K.; Voth, R.; Sivasupramanian, S.; Heering, D.; Carey, B. R. A. and Roberts, J. K. (2001): Development and commercial use of 
Bollgard ${ }^{\circledR}$ cotton in the USA early promises versus today's reality. Plant Journal, 27 (6):489-501.

Salama, H. S.; Abd El Bast, M. S. and Ragaei, M. (1992): Mode of action of chemical addetives in enhancing to potency of Bacillus thuringeinsis against lepidopterous insects. Journal of Applied Entomology, 114 (2): 167-173

Schnepf E.; Crickmore N.; van Rie J.; Lereclus D.; Feitelson J.; Zeigler D.R. and Dean D. H. (1998): Bacillus thuringiensis and its pesticide crystal proteins. Microbiological Molecular Biology Review, 62:775-806

Schuler, T. H.; Poppy, G. M.; Kerry, B. R. and Denholm, I. (1998): Insect resistant transgenic plants. Tibtechnology, 16: 168-175.

Talaei-Hassanloui, R.; Bakhshaei, R.; Hosseininaveh, V., and Khorramnezhad, A. (2014): Effect of midgut proteolytic activity on susceptibility of lepidopteran larvae to Bacillus thuringiensis subsp. kurstaki. Front Physiology, 4, 406-411.

Unnithan G. C.; Sarah B.; Brook W.; Yves C.; Bruce Tabashnik, and Timothy J. D. (2004): Susceptibility southwestern pink bollworm to Cry 2Ab: baseline responses. Proceeding of 2004 Beltwide Cotton Conferences, National Cotton Council, Memphis, TN.

Wei, Y.; Wu, S.; Yang, Y. and Wu, Y. (2017): Baseline susceptibility of field populations of Helicoverpa armigera to Bacillus thuringiensis Vip3Aa toxin and lack of cross resistance between Vip3Aa and Cry toxins. Toxins. 9:127 - 132.

Widner, W. R. and Whiteley, H. R. (1989): Two highly related crystal proteins of Bacillus thuringiensis var kurstaki possess different host range specificities. Journal of Bacteriology, 171:965-974

Wu, K. M. and Guo, Y. Y. (2005): The evolution of cotton pest management practices in China. Annual Review of Entomology, 50, 31-52.

Wu, K. M.; Lu, Y. H.; Feng, H. Q.; Jiang, Y. Y. and Zhao, J. Z. (2008): Suppression of cotton bollworm in multiple crops in China in areas with $B t$ toxin-containing cotton. Science, 321, 1676-1678.

Yamamoto, PT.; Benetoli, I.; Fernandes, O. D. and Gravena, S. (1990): Effect of Bacillus thuringiensis and insecticides Alabama argillacea (Hubner) (Lepidoptera: Noctuidae) and predatory orthropods. Ecossistema, 15: 36- 44.

Yiyun W.; Shuwen W.; Yihua Y. and Yidong W. (2017): Baseline Susceptibility of Field Populations of Helicoverpa armigera to Bacillus thuringiensis Vip3Aa Toxin and Lack of Cross-Resistance between Vip3Aa and Cry Toxins. Toxins, 9(4): 127- 130. 


\section{ARABIC SUMMARY}

\section{قابلية دودة ورق القطن المصرية للمبيدات البروتينية الحشرية Cry2AbوCry1Ac كأستجابات اساسية}

احمد محمد سالمان 1_ حسن فرج ضاحي 2_- اسماء محمود بديوي 2

$$
\text { 1 -قسم وقاية النبات - كلية الزر اعة - جامعة سوهاج }
$$

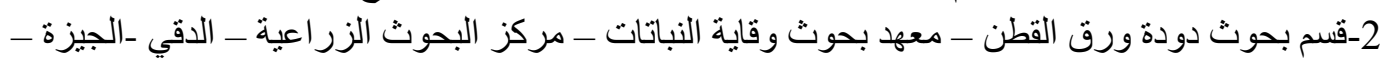

\section{مصر}

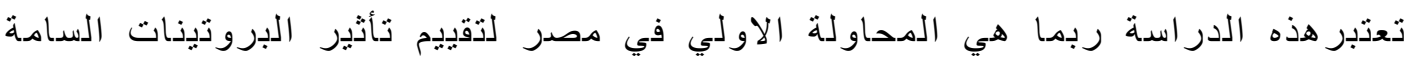

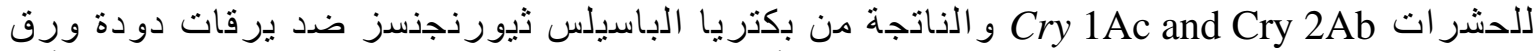

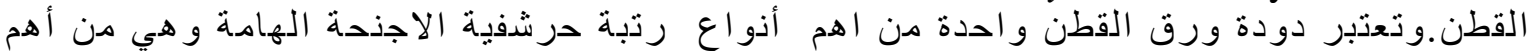

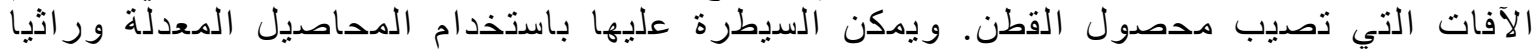

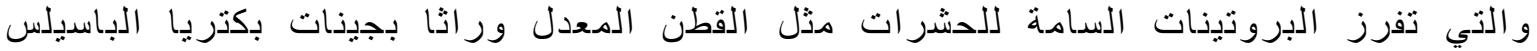

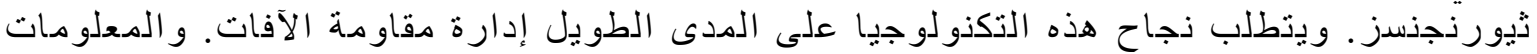

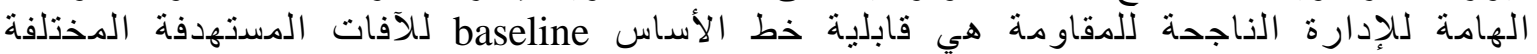

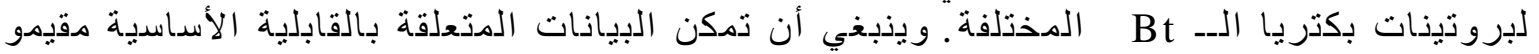

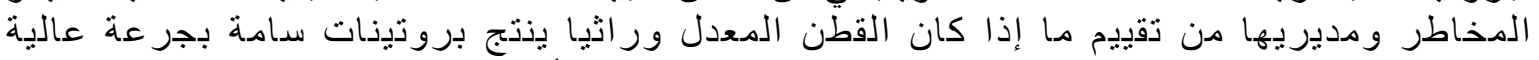

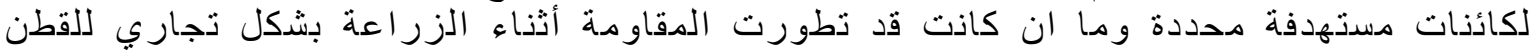

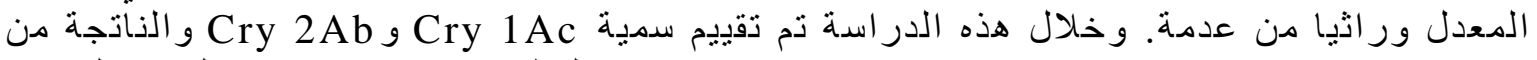

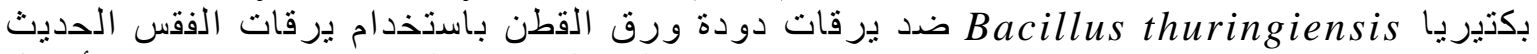

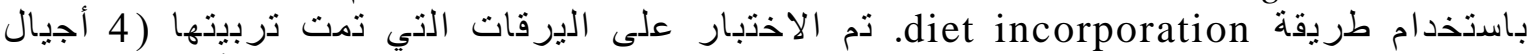

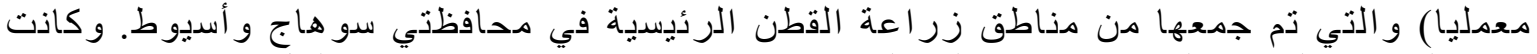

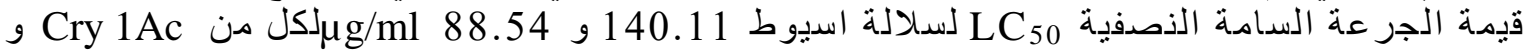

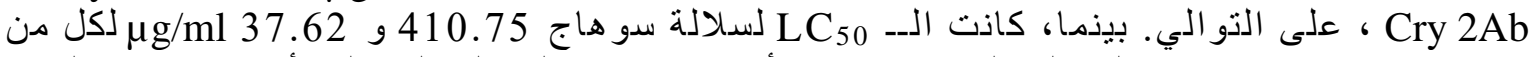

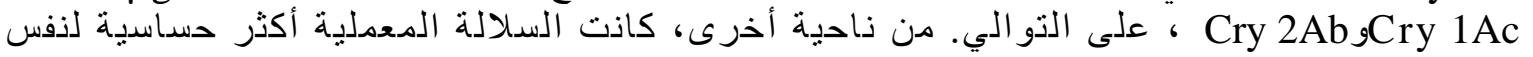

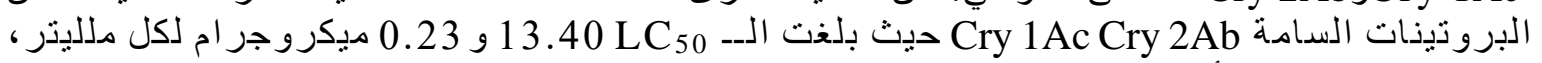

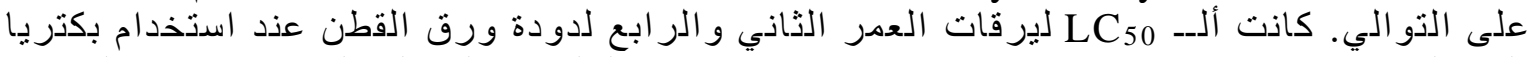

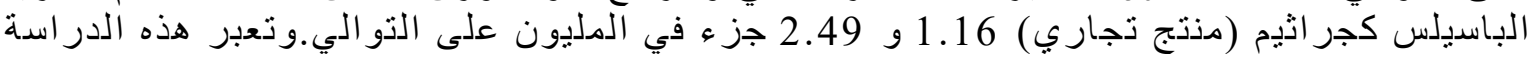

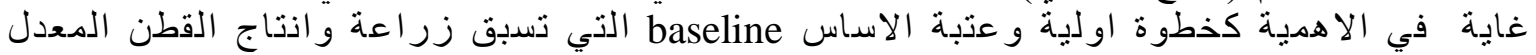
ور اثيا بصدورة تجارية الاهدية 